\title{
The Jourmal of
}
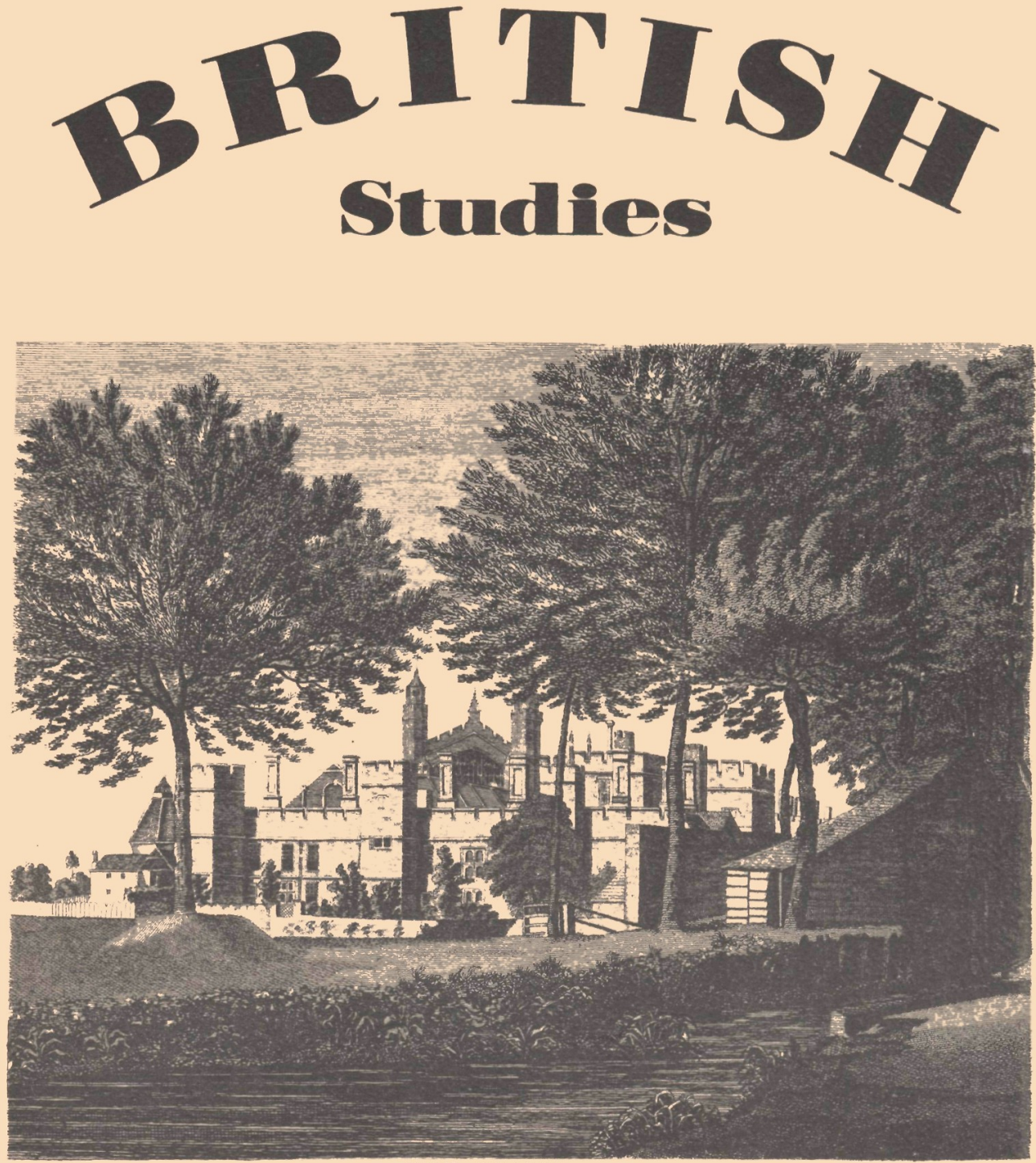

\section{FALL 1978}




\section{From the library of Peter Stansky}

Peter Stansky, Stanford University

David Roberts, Dartmouth College

David Underdown, Brown University
IG EDITOR

Cooper, Trinity College

iT EDITOR

Shyla Spear

BUSINESS MANAGER

Patricia A. McDonald

\section{BOARD OF ADVISORS}

H. J. Hanham, Massachusetts Institute of Technology

Gertrude Himmelfarb, Graduate Center, City University of New York

Maurice Lee, Jr., Douglass College, Rutgers University

F. M. Leventhal, Boston University

Bryce Lyon, Brown University

W. T. MacCaffrey, Harvard University
Helen F. Mulvey, Connecticut College Jacob M. Price, University of Michigan

Bernard Semmel, State University of New York, Stony Brook

Barbara Shapiro, University of California, Berkeley

Robert A. Smith, Emory University

Robin W. Winks, Yale University

\section{OVERSEAS CORRESPONDENTS}

Barbara Harvey, Somerville College, Oxford

Harold Perkin, University of Lancaster Keith Thomas, St. John's College, Oxford

\section{CONFERENCE ON BRITISH STUDIES}

\section{PRESIDENT}

Lacey Baldwin Smith, Northwestern University

ASSOCIATE EXECUTIVE SECRETARY

Reba N. Soffer, California State University, Northridge

RECORDING SECRETARY

Esther Cope, University of Nebraska
EXECUTIVE SECRETARY

Jacob M. Price, University of Michigan, Ann Arbor

TREASURER

Stuart E. Prall, Queen's College, C.U.N.Y.

PROGRAM CHAIRMAN

Anthony Wohl, Vassar College

\begin{abstract}
Annual subscription $\$ 8.00$ (two issues, Fall and Spring). Checks should be payable to the Journal of British Studies and directed to British Studies, Box 1315, Trinity College, Hartford, Connecticut 06106.

Contributors should send two copies of their manuscripts along with return postage to the EditorDesignate: Bentley B. Gilbert, Department of History, University of Illinois at Chicago Circle, Chicago, Illinois 60680 .
\end{abstract}

Information concerning membership in the Conference on British Studies may be obtained by writing to Stuart Prall, Department of History, Queen's College, C.U.N.Y., Flushing, New York 11367.

COVER: A view of Eton College, by Paul Sanciby, engraved by W. Godfrey, 1766. Repreduced by kind permission of the Lewis Walpole Library, Farmington, Connecticut. 


\section{The Journal of BRITISH Studies}

\section{CONTENTS}

Author

Title

Page

CARL I. HAMMER, JR. Anatomy of an Oligarchy: The Oxford Town Council in the Fifteenth and Sixteenth Centuries

OGBU U. KALU

Continuity in Change: Bishops of London and Religious Dissent in Early Stuart England

DEREK HIRST

The Privy Council and Problems of Enforcement in the $1620 \mathrm{~s}$

PETER ROEBUCK

Post-Restoration Landownership: The Impact of the Abolition of Wardship

WILLIAM C. LOWE

Bishops and Scottish Representative Peers in the House of Lords, 1760-1775

LEE KRENIS

Authority and Rebellion in Victorian Autobiography

J. M. McEWEN

The Struggle for Mastery in Britain: Lloyd George versus Asquith, December, 1916 ....

ANTHONY JAMES COLES The Moral Economy of the Crowd: Some Twentieth-Century Food Riots

\section{Published by}

The Conference on British Studies at Trinity College, Hartford, Connecticut Copyright 1978 by the Conference on British Studies at Trinity College, Hartford, Connecticut. Printed in the U.S.A. at The Bond Press, Inc., Hartford, Connecticut. 


\section{NOTES ON CONTRIBUTORS}

ANTHONY JAMES COLES is a post-graduate student at the University of Lancaster, where he is working on a study of "Problems and Policies in Health and Housing in West Cumberland, 1889-1939."

CARL I. HAMMER, JR. is a Fellow at the East Liberty Employment Security Institute at Pittsburgh. His articles on late-medieval and Tudor Oxford have appeared in Past and Present, Mediaeval Studies, and Vierteliahrschrift fiur Sozialund Wirtschaftsgeschichte. He is completing a demographic and social study of the Bavarian peasantry in the early Middle Ages.

DEREK M. HIRST is Associate Professor of History at Washington University, St. Louis. He is the author of The Representative of the People? (1975); and an article on the origins of the English civil war in the Journal of Modern History (1978). He is now working on a volume for the New History of England series to be published by Harvard University Press: Authority and Conflict, 1603-1658.

OGBU U. KALU is Senior Lecturer in Church History at the University of Nigeria, Nsukka. He has published Christianity in West Africa: The Nigerian Study (1977) and Divided People of God: Church Union Movement in Nigeria, 1876-1966 (1978). Some of his numerous articles have appeared in Church History, Missiology, International Review of Missions, and Journal of the Historical Society of Nigeria.

LEE KRENIS is a part-time Instructor in History and 'science writer' at the University of Rochester. She has a Ph. D. in English and is now working on a Ph. D. in History. The title of her thesis is "The Victorian Neurasthenic Establishment: The Sick Role and the Social System."

WILLIAM C. LOWE is Assistant Professor of History (Visiting) at Marshall University, Huntington, West Virginia. $\mathrm{He}$ has published an article on the bishops and the repeal of the Stamp Act in the Historical Magazine of the Protestant Episcopal Church (1977) and is now working on the rise of party in the House of Lords, 1760-1781.

J. M. McEWEN is Professor of History at Brock University, St. Catharines, Ontario. His articles have appeared in the Journal of British Studies, the Journal of Modern History, and Queen's Quarterly. His current research involves "Press and Politics in Britain during the First World War."

PETER ROEBUCK is Senior Lecturer in History at the New University of Ulster at Coleraine, Northern Ireland. He has published several articles on landownership and agriculture in 17th and 18th century England and has a book in press entitled, Yorkshire Baronets, Their Families and Estates, 1640-1760. He has served as joint editor of Irish Economic and Social History since its inception in 1974 and is now researching the history of landed estates in Britain and Ulster since the early 17 th century. 